\title{
At what costs? A proposal for estimating migration costs in the Bangladesh-Malaysia corridor
}

\author{
Shamim Ahmed Khan \\ School of Business, Monash University Malaysia, Bandar Sunway, Malaysia \\ Masnun Mahi \\ Faculty of Business and Accountancy, University of Malaya, Kuala Lumpur, Malaysia \\ Mohammad Zainuddin* \\ Putra Business School, Universiti Putra Malaysia, Serdang, Malaysia \\ Emadul Islam \\ University of Malaya, Malaysia; and BRAC, Dhaka, Bangladesh
}

\begin{abstract}
This article provides a comprehensive proposal to figure out the full spectrum of costs borne by Bangladeshi workers on their journey to Malaysia. The article proposes to consider the differences based on skill level, employment sector, immigration status, gender, traveling routes as well as channels and funding sources in order to determine the true economic cost of migration. The article also proposes to take social cost of migration into account. It sheds light on the effects of migration on migrant households with a view to fully comprehend the overall migration cost scenario. Finally, the paper suggests to take into consideration the impact of COVID-19 pandemic on broader migration and repatriation context.
\end{abstract}

Keywords: Migration, economic cost, social cost, Bangladesh, Malaysia, COVID-19

\section{Introduction}

Malaysia suffered severe labor shortage in the 1990s, and consequently entered into an agreement with Bangladesh, in 1992, for the transfer of labor on a large scale systematically. Prior to that, in 1986, Malaysia imported 500 Bangladeshis on a trial basis to service their plantation sector. After the agreement in 1992, the labor movement from Bangladesh to Malaysia accelerated (Sarker, 2016). The agreement was the beginning of a long relationship between Bangladesh and Malaysia on labor movement which was rather bumpy.

Malaysia entered into another agreement with Bangladesh in 1994 for importing 50,000 workers annually for their construction industry. During the Asian Financial Crisis, there was a sharp decline in the number of Bangladeshi workers in Malaysia when 100,000 of them were deported

${ }^{*}$ Corresponding author: Mohammad Zainuddin can be contacted at mohammad.msc hp17@grad.putrabs.edu.my 
in 1997. In subsequent years, Bangladesh started exporting skilled, semi-skilled and non-skilled laborers to Malaysia through registered recruiting agencies. In 2001, however, Malaysia terminated the agreement on labor export from Bangladesh and announced the restriction on labor importation formally. The latest suspension came in September 2018 following allegations that a syndicate of 10 Bangladeshi agents - with support from Malaysia - controlled labor recruitment in 2016-18 when recruitment cost went up to Tk. 4 lakh. However, both the countries subsequently agree to work together to establish a new memorandum of understanding (MOU) to reinstate the migration process. Such an effort is very significant from the viewpoint of establishing safe and legal migration and the proposed study is undertaken against this backdrop.

\section{Literature Review}

While legal, safe, and affordable migration policies are conducive to maintain the flow of labor forces between countries, improper protections and unchecked labor migration can increase the risk of human trafficking. Thus, efficient migration policies are crucial.

Malaysia has historically been one of the largest destinations of Bangladeshi migrant population which has great economic significance ${ }^{1}$. However, Bangladesh lost this prominent destination of migrant workers due to suspension as mentioned above. Previously, the high fees for migration charged by recruitment agencies forced the workers to take on crippling debts that all but enslaved them to their recruiters or employers. The joint effort to have a new MOU is thus crucial for establishing safe migration. It is also important for both countries; the economy of Bangladesh relies on remittances from its migrant workers; while Malaysia also depends significantly on migrant workers from Bangladesh to fill its factories and plantations.

A revamped $\mathrm{MOU}$ between the countries will not only ensure Bangladeshi workers to migrate with zero or minimal costs to Malaysia legally, but also help curb human trafficking and protect workers' rights. Specially, for Bangladesh, the MOU possesses greater significance as the country's total remittances by migrant workers is projected to fall by $25 \%$ due to the COVID-19 pandemic, as estimated by the World Bank ${ }^{2}$. Hence, the memorandum of understanding between Bangladesh and Malaysia with a view to re-establish the parameters of safe and legal migration is highly significant, and the proposed study aims to address research questions surrounding this.

In order to figure out the full spectrum of costs borne by Bangladeshi workers on their journey from Bangladesh to Malaysia, several factors need to be considered.

First, the type of workers, viz., unskilled, semi-skilled or skilled (Mannan, 2016). According to Maxwell (2010), 86.6 per cent of Bangladeshi workers migrated to Malaysia are unskilled, 13.2 per cent semi-skilled and 0.2 per cent skilled.

\footnotetext{
${ }^{1}$ In 2018-19 fiscal year, Bangladesh received $\$ 1.19$ billion in remittance from Malaysia. The amount is $7.25 \%$ of the amount that migrant workers sent home that year (The Daily Star: February 17, 2020).

${ }^{2}$ Source: COVID-19 crisis through a migration lens: migration and development brief 32 (World Bank: April 2020).
} 
Second, the employment sector for which the workers are being recruited is another decisive factor (Ishida \& Hassan, 2000; Abdul-aziz, 2001; Wickramasekara, 2015). Semi-skilled and unskilled workers mainly work in plantation and agricultural sectors (Robertson, 2008), whereas a small proportion work in the construction, manufacturing, and services sectors.

Third, Bangladeshi migrants in Malaysia can be grouped in terms of their immigration status (Hossain, Khan, \& Short, 2013). Some Bangladeshis enter Malaysia legally, while others enter illegally or become illegal at the expiry of contracts.

Fourth, the routes traveled are also important determinants of migration costs of Bangladeshi workers. In a detailed study, Ullah (2013) discovered six routes the migrants traveled to get to Malaysia, such as Bangladesh-Bangkok-Songkhla-through deep forest, Bangladesh-Hat YaiSungai-boat-forest-hill, Bangladesh-Bangkok-Yale-Sungai, Golok-forest-truck van, BangladeshSingapore-Malaysia, or directly from Dhaka. The majority went to Malaysia traversing Thailand or Singapore via various routes.

Fifth, channels and funding sources have important implications on migration cost (Hossain et al., 2013). Most government-approved agencies and financial institutions are urban-based, and as such, most rural migrants rely on informal sources such as middlemen and moneylenders who charge much higher fees and interest rates.

Sixth, another influencing factor is gender. Migration costs often differ considerably between male (Sarker 2016) and female (Parvin \& Rabbi, 2017) aspirants.

Finally, social cost of migration also needs to be considered, such as, chronic debt and destitution, family breakdown, disempowerment of migrant wives, rise in hedonistic behavior and school dropout rates (Hossain et al., 2013). The social costs are rarely reported due to complexities involved in assessment.

In the proposed study, our primary objective is to determine the true cost of migration, taking into account all the factors mentioned above. We will also evaluate the effect of COVID-19 pandemic on migration of workers from Bangladesh to Malaysia. In addition, our study attempts to come up with a solution for a new migration practice that is fair, transparent and efficient.

\section{Methodology}

The proposed study and its methods are aligned to the philosophy of pragmatism. Consequently, the study follows abductive logic with regard to its approach, and mixed methods of inquiry are adopted to achieve the research objectives. As to the time horizon, the study is cross-sectional in its design, and both survey and grounded theory will be used as research strategies. The rationale of selecting mixed method can be explained on the basis of research objectives of the study. The broad objective of the present study is to investigate the hidden cost associated with migration. Cost can be categorized into two forms, viz., economic and social cost. As economic cost is quantifiable, a quantitative study is best suited to identify the economic costs of migration. On 
the other hand, social costs cannot be quantified and subjective in nature. Therefore, to find out the social cost of migration, qualitative research design is considered appropriate.

\subsection{Sampling strategy}

For quantitative part of the study (i.e., to investigate the economic cost of migration), the sample size is selected based on the total number of migrant Bangladeshi workers in Malaysia. The exact number of migrant Bangladeshi workers in Malaysia has been reported differently in different sources. For this study, population and demography data published by the Department of Statistics Malaysia (DOSM) is considered as the reference point where it is reported that total number of foreign workers in Malaysia is 3.827 million (Loh, Simler, Tan Wei, \& Yi, 2019). This figure includes both regular and irregular foreign workers. Out of 3.827 million foreign workers, $14 \%$ are Bangladeshi workers, i.e., 535,780 to be exact (Loh et al., 2019). This is considered as our population of the study. However, it is to be noted that the unofficial estimate of foreign workers is much higher than the reported figure.

Based on the population, using the guideline of Krejcie \& Morgan (1970), sample size for the present study will be 382. Both documented and undocumented workers will be considered under this sample size. As there is no specific list consisting the profile of the Bangladeshi migrant workers that can be used as a sampling frame, non-probability sampling technique will be used. The method of sample selection will be a combination of convenient and snowball sampling. For documented workers, convenience sampling will be used as they can be easily approached. However, identifying undocumented workers is challenging since no one would want to reveal that they are undocumented. Therefore, undocumented workers will be identified using snowballing or chain-referral sampling.

On the other hand, for qualitative part of the study (i.e., to identify the social costs), in-depth interview will be conducted using theoretical sampling technique. In this technique, taking new sample is stopped only when theoretical saturation is reached. Our goal is to gain an in-depth understanding of the social costs of migration and develop a theoretical explanation. Hence, grounded theory research strategy (Glaser \& Strauss, 1967) will be used for the qualitative part.

\subsection{Data collection}

Primary data will be collected for the present study. For quantitative portion, data will be collected via structured interview using questionnaire. For qualitative part, in-depth interviews will be conducted. Data will be collected from Bangladeshi migrant workers residing in Selangor, Johore and Kuala Lumpur because these three states constitute $63 \%$ of the total foreign workers of Malaysia. To ensure that selected samples are representative of population as well as representative of the identified factors (six factors as mentioned in section 2), some control will be imposed in designing and carrying out the data collection. The intended data collection strategy is outlined below. 
The sample for the quantitative study will focus both documented and undocumented workers. Although finding and approaching undocumented workers will be challenging, the goal is to incorporate as many undocumented workers as possible within the sample size. At the very beginning, the survey will be executed by approaching the participants based on job sector. To ensure the representativeness, by keeping in line with the population, samples will be collected from the five job sectors, viz., agriculture, plantation, construction, manufacturing and service as these are the major employment sectors for foreign workers. The number of samples to be collected from each sector are outlined in Table 1. Furthermore, to confirm the representativeness based on gender, 306 male and 76 female Bangladeshi workers will be surveyed. There will be no question regarding Job sector or gender in the structured interview (survey questionnaire) because these two will be controlled by the researcher manually.

It is to be noted here that the number of samples based on job sector and gender is decided based on the statistics of "total foreign workers" in Malaysia; not "Bangladeshi workers" in Malaysia. We have made an assumption regarding Bangladeshi workers based on the statistics of total foreign workers as sector-wise or gender-wise statistics of Bangladeshi workers in Malaysia are not readily available.

It is expected that workers of every skill level (skilled, semi-skilled or unskilled) will get automatically covered because of taking samples from five different job sectors. Specifically, due to collection of data from agriculture and plantation sector, it is expected that unskilled and semiskilled workers will get covered as majority of the workers in these two sectors are either unskilled or semi-skilled (Robertson, 2008). Similar to the skill level, it is also expected that sample representation based on channel used (e.g. Govt. agencies/middleman/moneylender etc.) will get automatically covered due to the large number and diverse nature of sample size. Furthermore, it is evident that respondents using informal channels will be covered automatically because, as stated earlier, majority of the Bangladeshi workers in Malaysia are from rural areas of Bangladesh and usually tend to seek help of a middleman.

Ensuring participant representation based on "route to Malaysia" (i.e., coming to Malaysia through Singapore/Thailand/Dhaka) is considered challenging because workers coming through Singapore or Thailand are mainly undocumented workers. As such, due to the fear of revealing personal information or due to social desirability bias, it is possible that majority of the respondent will withhold the actual information regarding the route used. Therefore, initial idea is to keep this criterion open irrespective of route used. Sampling strategy/sample size/sampling frame will be adjusted accordingly based on initial findings. Table 1 outlines the details to ensure that the selected samples adequately represent the population. 
Table 1: Ensuring representativeness of sample

\begin{tabular}{|c|c|c|c|c|}
\hline & Criterion & Number & Justification & Source \\
\hline $\begin{array}{l}\text { Immigration } \\
\text { Status }\end{array}$ & $\begin{array}{l}\text { Documented \& } \\
\text { Undocumented } \\
\text { Workers }\end{array}$ & 382 & $\begin{array}{l}\text { - Survey will be conducted } \\
\text { on both types of workers. } \\
\text {-Sample size in accordance } \\
\text { with total population of } \\
\text { migrated workers. }\end{array}$ & $\begin{array}{l}\text { Loh et al. } \\
\text { (2019), } \\
\text { DOSM }\end{array}$ \\
\hline Job Sector & $\begin{array}{l}\text { Agriculture } \\
\text { Plantation } \\
\text { Construction } \\
\text { Manufacturing } \\
\text { Service \& Others }\end{array}$ & $\begin{array}{l}\text { Agriculture: } 34 \\
\text { Plantation: } 57 \\
\text { Construction: } 73 \\
\text { Manufacturing: } \\
138 \\
\text { Service \& Others: } \\
80\end{array}$ & $\begin{array}{l}\text {-These sectors constitute } \\
\text { majority foreign workers. } \\
\text { - 9\% Agriculture; } 15 \% \\
\text { Plantation; } 19 \% \\
\text { Construction; } 36 \% \\
\text { Manufacturing and } 21 \% \\
\text { Service and others. }\end{array}$ & $\begin{array}{l}\text { Loh et al. } \\
\text { (2019) }\end{array}$ \\
\hline Gender & $\begin{array}{l}\text { Male } \\
\text { Female }\end{array}$ & $\begin{array}{l}\text { Male: } 306 \\
\text { Female: } 76\end{array}$ & $\begin{array}{l}80 \% \text { Male; } 20 \% \text { Female } \\
\text { (Gender ratio of total } \\
\text { foreign workers in } \\
\text { Malaysia). }\end{array}$ & $\begin{array}{l}\text { Loh et al. } \\
\text { (2019) }\end{array}$ \\
\hline Skill Level & $\begin{array}{l}\text { Unskilled } \\
\text { Semi-Skilled } \\
\text { Skilled }\end{array}$ & 382 & $\begin{array}{l}\text { Respondents from } \\
\text { agriculture \& plantation } \\
\text { will fall automatically } \\
\text { under either unskilled or } \\
\text { semi-skilled. }\end{array}$ & $\begin{array}{l}\text { Maxwell } \\
(2010)\end{array}$ \\
\hline Channel & $\begin{array}{l}\text { Will be kept } \\
\text { open } \\
\text { (Irrespective of } \\
\text { govt. Agencies / } \\
\text { middleman) }\end{array}$ & 382 & $\begin{array}{l}\text { - As no statistical } \\
\text { information is available } \\
\text { regarding how many came } \\
\text { to Malaysia via direct govt. } \\
\text { agencies or middleman }\end{array}$ & - \\
\hline Route & $\begin{array}{l}\text { Will be kept } \\
\text { open } \\
\text { (Irrespective of } \\
\text { Dhaka, } \\
\text { Singapore or } \\
\text { Thailand) }\end{array}$ & 382 & $\begin{array}{l}\text {-Although many workers } \\
\text { enter Malaysia via Thailand } \\
\text { or Singapore; they mostly } \\
\text { consist of undocumented } \\
\text { workers. (Ullah 2013) } \\
\text {-Therefore, due to "social } \\
\text { desirability bias", it is } \\
\text { possible that majority of } \\
\text { the workers would not } \\
\text { reveal the actual route } \\
\text { information in survey }\end{array}$ & $\begin{array}{l}\text { Ullah } \\
\text { (2013) }\end{array}$ \\
\hline
\end{tabular}

For qualitative study, as data will be collected via in-depth interview to develop a theory about social costs of migration, the focus will be to collect interview from as diverse sample as possible 
which would include not only different types of workers but also the migrant households in Bangladesh. The goal is to take interview until theoretical saturation is reached. The interview will be recorded via audio form which will then be transcribed and analyzed.

\subsection{Data analysis}

Considering the sensitivity of the study topic, the collected data will be completely anonymous. Informed consent will be obtained from the participants to take part in the survey/in-depth interview. Participants will be ensured that their identity will be kept confidential.

To analyze the quantitative data, necessary graphical analysis and statistical analysis will be conducted. Descriptive and inferential statistics will be used to summarize and report the findings. Relevant bar graphs and pie charts will also be used to present the findings. To analyze the qualitative data collected via interview, coding and constant comparison will be followed. Based on the guideline of grounded theory strategy, concurrent data collection and analysis will be conducted, and open coding, axial coding and selective coding will be used to make comparison and develop conceptualization or theoretical explanation about social costs of migration.

Moreover, a number of individuals, other than workers, who are involved in the migration process, such as, relevant government officials, recruiting agencies, middlemen (broker, sub-broker) and employer will be interviewed selectively to get an overall picture of migration. Notably, the disruption caused by COVID-19 on migration will be taken into account in both data collection and analysis. A summary of our proposed methodology is given in Table 2.

Table 2: Research design, data collection and analysis

\begin{tabular}{|c|c|c|}
\hline \multirow{5}{*}{ Research design } & Research philosophy & Pragmatism \\
\hline & Research approach & Abductive \\
\hline & Methodological choice & Mixed (quantitative, qualitative) \\
\hline & Research strategy & Survey, grounded theory \\
\hline & Time horizon & Cross-sectional study \\
\hline \multirow{2}{*}{$\begin{array}{l}\text { Sampling } \\
\text { technique }\end{array}$} & Quantitative & Convenient, snowball sampling \\
\hline & Qualitative & Theoretical sampling \\
\hline \multirow[t]{2}{*}{ Sample size } & Quantitative & 382 \\
\hline & Qualitative & Theoretical saturation \\
\hline \multirow[t]{2}{*}{ Data collection } & Quantitative & Structured interview (questionnaire) \\
\hline & Qualitative & In-depth interview \\
\hline \multirow[t]{2}{*}{ Data analysis } & Quantitative & $\begin{array}{l}\text { Graphical (bar, pie), statistical (descriptive, } \\
\text { inferential). Tool: SPSS }\end{array}$ \\
\hline & Qualitative & $\begin{array}{l}\text { Concurrent collection \& analysis: Coding, } \\
\text { constant comparison. Tool: NVivo }\end{array}$ \\
\hline
\end{tabular}




\section{Conclusion}

Our study is expected to determine the full spectrum of costs borne by Bangladeshi workers on their journey to Malaysia. The study includes a wide variety of Bangladeshi migrant workers to understand the differences based on skill level, employment sector, immigration status, traveling routes, gender, as well as channels and funding sources. It collects and analyzes data not only from migrant workers but also from different agencies, sub-agents and local brokers in order to comprehend the overall scenario of migration.

In addition, our study takes social costs into account and assesses the impact of migration on migrant households. Besides, the impact of COVID-19 pandemic on migration and repatriation scenario is also taken into consideration. The proposed research will also shed light on the cost of living and ability to recuperate expenses amongst migrants. Finally, the study attempts to provide solutions for a new recruitment process and practices that are accessible, wellmonitored, efficient and transparent.

The proposed study has some limitations. For instance, the unavailability of reliable statistics of migrants as well as limited coverage of illegal workers pose significant limitations. In addition, there may be limited access to some important documents on the grounds of confidentiality by Governments and recruiting agencies. Moreover, it may be difficult to interview workers in the present situation when movement control order or lockdown is in place.

\section{References}

Abdul-Aziz, A. R. (2001). Bangladeshi migrant workers in Malaysia's construction sector. Asia Pacific Population Journal, 16(1), 3-22.

Department of Statistics, Malaysia (DOSM). (2018). Current Population Estimates. Retrieved from https://newss.statistics.gov.my/newssportalx/ep/epFreeDownloadContent Search.seam? cid=325813

Glaser, B., \& Strauss, A. (1967). The discovery of grounded theory. 1967. Weidenfield \& Nicolson, London, 1-19.

Hossain, M. I., Khan, M. A., \& Short, P. (2013). Migration of Bangladeshi workers to Malaysia: emerging lessons of economic and social costs and benefits at the migrant, migrant household and community levels. In The Asian Century, Sustainable Growth and Climate Change. Edward Elgar Publishing.

Ishida, A., \& Shahid Hassan, M. D. (2000). Why do migrant workers intend to extend their stay in host countries? The case of Bangladeshi workers in Malaysia's manufacturing sector. International Migration, 38(5), 100-115. 
Krejcie, R. V., \& Morgan, D. W. (1970). Determining sample size for research activities. Educational and psychological measurement, 30(3), 607-610.

Loh, W. S., Simler, K., Tan Wei, K., \& Yi, S. (2019). Malaysia-Estimating the Number of Foreign Workers: A Report from the Labor Market Data for Monetary Policy Task (No. AUS0000681, pp. 1-62). The World Bank. Retrieved from http://documents.worldbank.org/curated/en/953091562223517841/Malaysia-Estimating- theNumber-of-Foreign-Workers-A-Report-from-the-Labor-Market-Data-for-Monetary- Policy-Task

Mannan, D. K. A. (2016). Labor migration between developing economy to developing country: A case study of Bangladesh and Malaysia. International Journal of Migration Research and Development (ISSN: 2411-9695), 2(1).

Maxwell Stamp Limited (2010). Study on the International Demand for Semi-skilled and Skilled Bangladeshi Workers, TVET Reform Project, Bangladesh.

Parvin, H., \& Rabbi, F. (2017) Factors Effecting Female Migration: Bangladesh Perspectives. Malaysian Construction Research Journal (MCRJ), 126.

Robertson PS Jr. (2008) Migrant Workers in Malaysia - Issues, Concerns and Points for Action. Washington, DC: Fair Labor Association.

Sarker, R. (2016). Migration and employment: A study of Bangladeshi male migrant workers in Malaysia. In International Migration in Southeast Asia (pp. 125-148). Springer, Singapore.

Ullah, A. A. (2013). Theoretical Rhetoric About Migration Networks: A Case of a Journey of Bangladeshi Workers to Malaysia. International Migration, 51 (3), 151-168.

Wickramasekara, P. (2015). Bilateral agreements and memoranda of understanding on migration of low skilled workers: a review. Available at SSRN 2636289. 